\title{
A cornual ectopic pregnancy case: diagnosis, etiology and its management
}

\author{
Wachyu Hadisaputra \\ Division of Reproductive Health, Department of Obstetrics and Gynecology, Faculty of Medicine University of Indonesia/ \\ Dr. Cipto Mangunkusumo General Hospital, Jakarta
}

\begin{abstract}
Abstrak
Tulisan ini menyajikan laporan kasus mengenai kehamilan ektopik, peran ultrasonografi transvaginal dalam mendeteksi secara dini, penapisan, pengukuran $\beta-h C G$, serta peran methotrexate sebagai terapi sebelum melakukan tindakan operatif pada kehamilan ektopik kornu yang ditatalaksana secara konservatif. Mioma intramural multiple (22 buah) pada kasus ini ditengarai sebagai penyebab kehamilan kornunya. (Med J Indones 2008; 18: 64-8)
\end{abstract}

\begin{abstract}
This is a report of a case of cornual ectopic pregnancy, with transvaginal ultrasonography done for early detection, screening, $\beta$-hCG measuring, also discussed was the role of methotrexate therapy prior to operative procedure with conservative management. Multiple intramural myomas (22 myomas) in this case were strongly believed as the etiology of the cornual pregnancy. (Med J Indones 2008; 18: 64-8)
\end{abstract}

Keywords: Cornual ectopic pregnancy, multiple myomas, ultrasonography, methotrexate

Ectopic pregnancy is a condition with gestation sac located outside the uterine cavity, which is a major life threatening situation in early pregnancy. The incidence in the United States has increased in the last five decades, from 4,5 per 1000 pregnancy in 1970 to 19,7 per 1000 pregnancy in $1992 .{ }^{1,2}$ Spontaneous rupture could happen, patients have risk to tubal rupture and catastrophic bleeding. Ectopic pregnancy is still a leading cause of maternal mortality which includes approximately $4 \%$ from 20 deaths associated with pregnancy each year in Canada. ${ }^{1}$ The frequency is relatively high from this condition so early detection is still a challenge up till now. Approximately half of the women with ectopic pregnancy who came to the emergency unit, were not detected through early assessment. In general population, the incidence of ectopic pregnancy is about $2 \%$ and the prevalence among pregnant women who came to emergency unit with bleeding and / or pain in the first trimester is $6 \%-16 \%{ }^{3}$

Availability of advanced hormonal marker and ultrasound imaging have increased the complexity of complete diagnostic in ectopic pregnancy (EP) suspected patients, and evolution from less invasive surgery technique and also non-invasive medical treatment have changed the situation and treatment strategy. This literature summarized some advanced literatures which discuss the outcomes from advance technology in diagnosis and treatment of cornual ectopic pregnancy as a rare case. Also in this journal present one case of the cornual ectopic as happened to the 42 years old woman with primary infertility and multiple myomas in her uterus. Rather then common cornuectomy surgery, in this case the operator performed conservative management (linear incision in cornu area).

\section{DIAGNOSIS}

Ectopic pregnancy is usually being diagnosed in the first trimester of pregnancy. Gestation age is usually 6-10 weeks when the diagnosis is made. Ectopic pregnancy has almost the same frequency in the large population of maternal age and ethnic origin. Documentation about risk factors is an essential part of anamnesis, and asymptomatic patients with risk factors can benefit from routine early imaging. ${ }^{1}$ But, more than half EP identified are women without obvious risk factors. ${ }^{4,5}$

Physical findings are dependent on whether or not uterine rupture has happen. Women with intraperitoneal bleeding came with abdominal pain, accompanied with several degree of hemodynamic instability. But, women without rupture could have come with pelvic pain, vaginal bleeding, or both. Several researchers have measured predictive value from particular risk 
factor and physical findings only or with combined. No combining is accurate and consistent in excluding EP.

This case diagnosed very accurately by transvaginal ultrasonography. With the finding of gestational sac in the left cornual area. Without prompt diagnostic it will be lost of timing for good result of surgery. Which if late in diagnosis, then the cornual rupture could happen.

\section{Screening with Measuring $\beta$-hCG (Human Chorionic Gonadotropin)}

Is important to have a definitive diagnose. In clinical settings, pregnancy is diagnosed with determination of urine or serum concentration of $\beta$-hCG. This hormone could be detected in urine and blood as early as one week before expected menstruation period. Serum test could detect low level to $5 \mathrm{IU} / \mathrm{l}$, mean while urine test could only detect low level to 20-50 IU/1. ${ }^{7}$ In most cases, screening could only be done with urine test, because $\beta$-hCG serum test require longer time and not always could be done any time. But, if there is a suspicion on pregnancy, even though the urine test is negative, serum test will give a definitive result.

If $\beta$-hCG serum level is low $(<1000 \mathrm{IU} / 1)$, then it is associated with higher risk to EP. Although serum level is very low $(<100 \mathrm{IU} / 1) 29 \%$ from them is found to have tubal rupture on laparoscopy. Another research find 38 tubal rupture in serum level 10 until 189, 720 $\mathrm{IU} / 1 .^{3}$ So single $\beta$-hCG serum measurement could not exclude EP or predict rupture.

Serial $\beta$-hCG measurement is often used for women with bleeding or pain in first trimester, or both. As with single measurement, serial measurement could not locate gestational sac. In normal pregnancy, $\beta$-hCG concentration first trimester increase rapidly, doubles for 2 days. An increase, for 48 hours, at least $66 \%$ has been used for cut off point for viability. Ectopic pregnancy could be found with increased, decreased, or steady $\beta$-hCG level. So serial measurement is very valuable to assure fetal viability compare to identification only of ectopic pregnancy.

\section{Ultrasound Imaging}

Transvaginal ultrasound has change evaluation of troubled early pregnancy, with the possibility to visualize earlier and more clearly the development of normal or abnormal embryo. A normal gestational sac, an ovoid liquid accumulation near endometrial line, could be visualized with transvaginal probe in gestational age of 5 weeks.

Often could be seen when diameter 2 or $3 \mathrm{~mm}$ and should be seen consistently at $5 \mathrm{~mm}$. Because hormonal environmental in EP could produce accumulation of liquid intrauterine with mimicking a gestational sac (pseudo gestational sac), hence just by finding a sac, not assuring intrauterine pregnancy. ${ }^{8}$ Ultrasound findings in EP is broad. Identification of gestational sac extrauterine which contains yolk sac (with or without embryo) stands for EP diagnosis.

Many prospective researches has shown transvaginal ultrasound imaging in clinical setting have high accuracy in assuring intrauterine and extrauterine pregnancy. Most of the protocols shows that definitive diagnosis could be build in initial assessment of more than $75 \%$ patients in clinical setting. Hence transvaginal ultrasound screening is a must, especially in patient who complain bleeding or pain in first trimester pregnancy. ${ }^{8,9}$

\section{TREATMENT}

\section{Medicinal Treatment}

Methotrexate (MTX), a folic acid antagonist, inhibits the synthesis of DNA in actively proliferating cells, including the trophoblasts. if given to a well-selected patient, the success rate could achieves $94 \%{ }^{8}$ The success of ectopic pregnancy treatment mostly depends on the serum concentration of $\beta$-hCG. A meta-analysis of 1.327 women with ectopic pregnancy who was treated with MTX shows that the resolution has a reverse association with the level of $\beta$-hCG and the increasing level of $\beta$-hCG has a correlation with the failure of treatment. The embryonic cardiac activity is also associated with the failure of MTX therapy. However, neither the diameter of the fallopian tube nor the size of the fetus is related to the outcome. ${ }^{8,9}$

The criteria of MTX therapy for ectopic pregnancy is as listed below: 
Table 1. Randomized clinical trial which compare methotrexate (MTX) with laparoscopic salphingostomy (LS) for ectopic pregnancy. ${ }^{9}$

\begin{tabular}{|c|c|c|c|c|c|}
\hline & \multicolumn{3}{|c|}{ The success rate of therapy $(\%)$} & \multirow[t]{2}{*}{ Other outcome } & \multirow[t]{2}{*}{ Comments } \\
\hline & MTX & LS & Differences of Rate & & \\
\hline $\begin{array}{l}\text { Hajenius et all, } \\
1997(100)\end{array}$ & 82 & 72 & NS & $\begin{array}{c}\text { No differences in the } \\
\text { level of tuba preservation }\end{array}$ & $\begin{array}{l}\text { All patients were going } \\
\text { through laparatomy for } \\
\text { diagnosis and therapy. } \\
\text { four dose of MTX. }\end{array}$ \\
\hline $\begin{array}{l}\text { Fernandez et al, } \\
1990(100)\end{array}$ & 88 & 96 & NS & $\begin{array}{l}\text { Future pregnancy } \\
\text { rate is higher in the } \\
\text { MTX Group ( } 96 \% \text { vs. } \\
62 \%, \mathrm{p}<0.05) \text { but not } \\
\text { for repeated ectopic } \\
\text { pregnancy }\end{array}$ & $\begin{array}{l}\text { One of some centre that } \\
\text { using the score system } \\
\text { and local injection } \\
\text { of MTX for ectopic } \\
\text { pregnancy }\end{array}$ \\
\hline $\begin{array}{l}\text { Sarajetal, } 1998 \\
\text { (75) }\end{array}$ & 95 & 91 & NS & $\begin{array}{l}\text { There's no differences in } \\
\text { the patency level or the } \\
\text { rate of future pregnancy }\end{array}$ & $\begin{array}{l}\text { This research is not } \\
\text { complete }\end{array}$ \\
\hline $\begin{array}{l}\text { Sowteretal, } \\
2001(62)\end{array}$ & 65 & 91 & $95 \% \mathrm{Cl} 10-47$ & $\begin{array}{l}\text { Less time for } \beta \text {-hCG } \\
\text { clearance in the LS } \\
\text { group: } 15(5-49) \text { vs. } 28 \\
(14-71) \text { d. }\end{array}$ & $\begin{array}{l}\text { This research represents } \\
\text { the clinical treatment for } \\
\text { ectopic pregnancy }\end{array}$ \\
\hline
\end{tabular}

Overall the success rate of MTX therapy is better in double dose than single dose (93\% vs. $88 \%$ ). However, the single dose regiment is cheaper, the rate of side effect is lower ( $29 \%$ vs. $48 \%)$, only need a less intensive observation, doesn't need the addition of folic acid, and effective for most of the cases. The two regiments haven't been compared directly in a random experiment. With the presence of the contraindications, as in the high level of serum concentration of $\beta$-hCG and embryonic cardiac activity, then the double dose regiment must be considered. The patients that are treated with MTX must be observed intensively. The serum concentration of $\beta$-hCG must be measured every week.

Protocol for MTX therapy that often followed internationally is as listed below':

- Pra-therapy Examination

- Complete blood count

- Determine blood type and the presence of antibody

- Determine liver and kidney function

- Measure serum concentration of $\beta$-hCG

- Do an transvaginal USG

- Day 0 medication

- MTX injection $\left(50 \mathrm{mg} / \mathrm{m}^{2}\right)$ intramuscularly

- RhoGAM injection (300 $\mu$ g)intramuscularly if needed
- Stop the folic acid supplement

- Advise to patient to limit physical activity and sexual contact

- $\quad$ Day 7

- Measure serum concentration of $\beta$-hCG

- Inject the second dose of MTX if the descent of $\beta$-hCG is $<25 \%$

- Weekly

- Measure serum concentration of $\beta$-hCG until the cocentration is $<15 \mathrm{IU} / 1$

- Do an USG transvaginal

- Everytime

Perform a laparascopy if the patient has acute abdomen or severe abdominal pain or the ultrasonography showed an intrabdominal bleeding $>100 \mathrm{ml}$.

The side effect of MTX therapy is usually not serious and limited, the most common being stomatitis and conjunctivitis. The other side effects that rarely occurred include pleuritis, dermatitis, alopecia, gastritis, enteritis, the increasing liver enzyme, and suppression of bone marrow that seldom happened. Approximately $30 \%$ patients will have adverse effect with single dose and $40 \%$ with double dose. ${ }^{10}$ 


\section{CORNUAL ECTOPIC PREGNANCY}

Cornual pregnancy is defined as the implantation of the trophoblast in the cornual part of the uterus. Cornual pregnancy is only found in 2-4 percent of the ectopic pregnancies, with an estimated occurrence of one in every 2500-5000 deliveries. ${ }^{10}$ The diagnosis of a cornual pregnancy in early gestation is difficult. Uterine bleeding, pelvic pain and rupture occurs later in cornual pregnancy when compared to an ectopic pregnancy located in the fallopian tube. ${ }^{10}$ The gestational sac in the uterine cavity if in a very lateral position, can be shown using transvaginal echography. ${ }^{10}$ In some cases, magnetic resonance imaging (MRI) can be used to confirm a suspected cornual pregnancy. As cornual pregnancies are located close to the uterine blood supply, rupture of cornual pregnancies may cause severe bleeding. This bleeding can be excessive, leaving hysterectomy as the only option.

\section{CASE ILLUSTRATION}

Mrs Z, 42 years old, with primary infertility for 2 years was admitted to the hospital at August $15^{\text {th }} 2008$ (in Bunda Maternity hospital, Jakarta) suffering slight vaginal bleeding, her last menstrual period was June $10^{\text {th }} 2008$. The laboratory result: $\mathrm{Hb} 13,3 \mathrm{~g} \%$, Leucocyte 12.500/ $/ \mathrm{mm}^{3}$, Blood group O Rh +, Glucose $97 \mathrm{mg} / \mathrm{dl}$, ECG was within normal limit.

Transvaginal ultrasonography examination found multiple myomas in the uterus measuring vary between $4,5 \mathrm{~cm}$ up to $1,0 \mathrm{~cm}$ (approximately 22 myomas). The uterine cavity was empty, but gestational sac present in the left cornu with the presentation of the fetal pole diameter $1,7 \mathrm{~cm}$ correspond to $8-10$ weeks gestational age. The patient was decided to undergo laparatomy. Prior to the surgery, double dose of $25 \mathrm{mg}$ of methotrexate (MTX) was administered with the interval of 24 hours. Patient underwent laparotomy on August $31^{\text {st }} 2008$.

During laparotomy, considering that the patient had taken MTX, the operator performed linear incision longitudinally in the left cornual, approximately $2 \mathrm{~cm}$, to remove the fetus and placenta completely (Figure 1) the bleeding was completely controlled by two layer stitching using vicryl no. 1 then the surgery followed by myomectomy, taken out the 22 myomas (diameter of 4,5 until $1,0 \mathrm{~cm}$ ), occupied diffusely in the uterine corpus (Figure 2).

Total surgical bleeding was approximately $200 \mathrm{ml}$. Patient were not received blood transfusion at all. Post- operatively patient's condition was stable and was discharged from the hospital 3 days after.

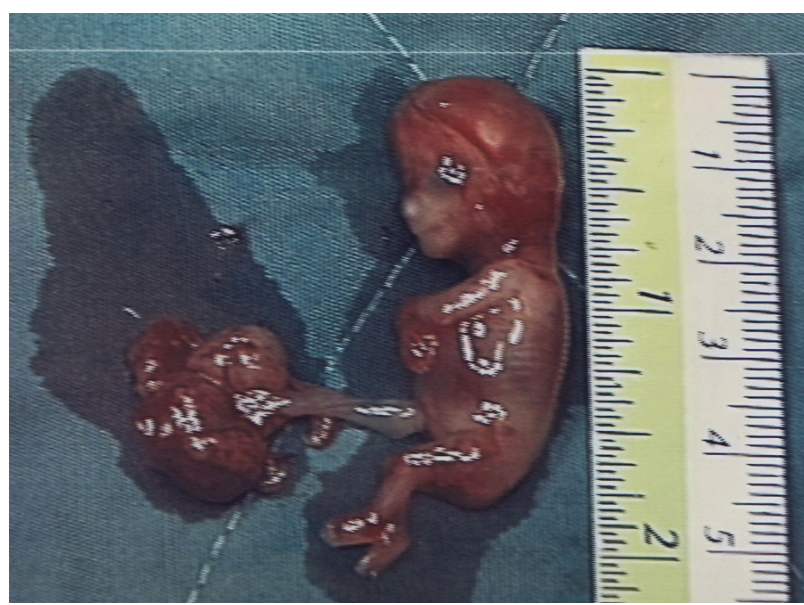

Figure 1. The fetus and placenta were completely removed.

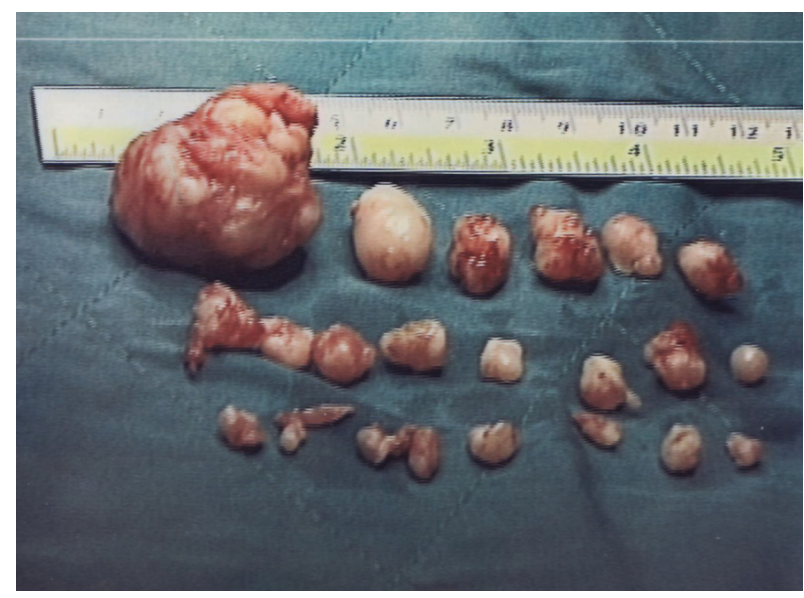

Figure 2. Multiple Myomas. The 22 myomas were removed. Their size varied between $1-4.5 \mathrm{~cm}$.

\section{DISCUSSION}

The cornual gestation which is most often surgically excised, require the removal of a portion of myometrium as well. A minimum amount of tissue must be excised in order to prevent possible uterine rupture in the future. ${ }^{11}$

Regarding this case, it was very surprising that MTX administered prior to surgery is invaluable with minimal bleeding at the time of cornual incision. So, only a linear cornu incision was needed. With the availability of transvaginal ultrasonography early diagnosis of cornual pregnancy can be performed and thus rupture complication can be prevented. ${ }^{8}$

The etiology of the cornual ectopic pregnancy in this case was strongly believed as due to the presence of 
multiple myomas in the uterus so the implantation occured in the area which was free from myoma, which was in the left cornu.

Different than common approach which performed cornual resection, In this case we performed linear incision to maintain intact cornu.

It is assumed that performing conservative approach in the cornu will make patient's reproductive function better than any other way.

\section{CONCLUSION}

1. Utrasonography is very invaluable in early diagnosis of ectopic pregnancy.

2. MTX has an important role in surgical conservative approach of cornual ectopic pregnancy.

3. Multiple intramural myomas which occupied the myometrium diffusely can cause cornual ectopic pregnancy.

4. By early diagnosis, even ectopic site in the cornu, conservative treatment to conserve cornu is possible.

\section{REFERENCES}

1. Martinelli P, Maruotti GM, Oppedisano R, et al. Is uterine artery embolization for cervical ectopic pregnancy always safe?. The Journal of Minimally Invasive Gynecology. 2007. 14(26): 758-63.
2. Davey A, Maher PJ. Surgical adhesion: A timely update, a great challenge for the future. The Journal of Minimally Invasive Gynecology. 2007. 14(1):15-22.

3. Abusheika N, O. Salha, et al. Extra-uterine pregnancy following assited conception treatment. Human Reproduction Update. 2000. 6(1): 80-92.

4. Buckley RG, King KJ, Disney JD, Gorman ID, Klausen $\mathrm{JH}$. History and physical examination to estimate the risk of ectopic pregnancy: validation of a clinical prediction model. Ann Emerg Med 1999; 34: 589-94. Comment in Ann Emerg Med 1999; 34: 664-7

5. Dart RG, Kaplan B, Varaklis K. Predictive value of history and physical examination in patients with suspected ectopic pregnancy. Ann Emrg Med 1999; 33: 283-90

6. Mol BW, Hajenius PJ, Engelshel S, Ankum WM, van der Veen F, Hemrika DJ, et al. Can noninvasive diagnostic tools predict tubal rupture or active bleeding in patients with tubal pregnancy? Fertil Steril 1999; 71: 167-73

7. Cash RL, Rahmani R, et al. First trimester screening aids in the diagnosis and management of an ectopic pregnancy in a noncommunicating uterine horn. Journal of Clinical Ultrasound. 2006. 34(9):446-9.

8. Mavrelos, D. E. Sawyer, et al. Ultrasound diagnosis of ectopic pregnancy in the non-communicating horn of a unicornuate uterus (cornual pregnancy). Ultrasound in Obstetric \& Gynecology. 2007. 30(5): 765-70.

9. Murray H, Baakdah H, Barden T, Tulandi T. Diagnosis and treatment of ectopic pregnancy synthese. CMAJ. Oct, 11, 2005: 905-12

10. Donnez J, Nisolle M. The encyclopedia of visual medicine series: an atlas of operative laparoscopy and hysteroscopy, $2^{\text {nd }}$ edition. Canforth, Lancs, UK: The Parthenon Publishing Group 2001;15:155-60.

11. Tinneberg HR, Tinneberg R. Laparoscopic Management of Ectopic Pregnancy. In Allahbadia GN, Merchant R. Gynecological Endoscopy and Infertility. Jaypee Brothers Medical Publishers. 2005:535-41. 